\title{
Experimental physiology, Everest and oxygen: from the ghastly kitchens to the gasping lung
}

\author{
VANESSA HEGGIE*
}

\begin{abstract}
Often the truth value of a scientific claim is dependent on our faith that laboratory experiments can model nature. When the nature that you are modelling is something as large as the tallest terrestrial mountain on earth, and as mysterious (at least until 1953) as the reaction of the human body to the highest point on the earth's surface, mapping between laboratory and 'real world' is a tricky process. The so-called 'death zone' of Mount Everest is a liminal space; a change in weather could make the difference between a survivable mountaintop and a site where the human respiratory system cannot maintain basic biological functions. Predicting what would happen to the first human beings to climb that high was therefore literally a matter of life or death - here inaccurate models could kill. Consequently, high-altitude respiratory physiology has prioritized not the laboratory, but the field. A holistic, environmentally situated sort of science used a range of (often non-scientific) expertise to prove the laboratory wrong time after time. In so doing, Everest was constructed paradoxically both as a unique field site which needed to be studied in vivo, and as a 'natural laboratory' which could produce generalizable knowledge about the human (male) body.
\end{abstract}

On 30 March 1874, French physiologist Paul Bert ascended to the summit of Mount Everest. He took with him a candle, a rat and an unlucky sparrow, which was very distressed by the ascent and vomited near the summit. Bert, breathing supplemental oxygen, felt in relatively good health, and was enough in control of his faculties to take a rectal temperature from the shivering bird (this proved to have fallen over five degrees Fahrenheit from its sea-level value). In fact Bert claimed that he had wanted to climb higher, and was only prevented from doing so by a malfunctioning steam pump. ${ }^{1}$

It is obviously disingenuous to call Bert's experience an 'ascent of Everest'. He never left his laboratory at the Sorbonne in Paris, approximately four and a half thousand miles from the Nepali region of the Himalaya. He had not spent weeks trekking to base camp, or negotiating crevasses, glaciers and deadly ice fields. He had not experienced bouts of dysentery or frostbite, or temperatures below $-20^{\circ}$ centigrade. He had not left

* Department of History and Philosophy of Science, University of Cambridge, Free School Lane, Cambridge, CB2 3RH, UK. Email: vh261@cam.ac.uk.

As this research is just part of a much larger project, it has accrued many debts, not least to the co-funders, the Wellcome Trust and the Isaac Newton Trust. Thanks are due to the archivists at the Wellcome Library, the Mandeville Special Collections Library at UC San Diego, and the Royal Geographical Society; to Ms Harriet Tuckey and Professor John West for information and inspiration; and to Dr Andrew Murray and Dr Mike Grocott (and the members in general) of the Caudwell Xtreme Everest Expedition. This article has been substantially improved by feedback from the audience of my Departmental Seminar at the Department of History and Philosophy of Science, Cambridge, from Simon Schaffer and from two reviewers.

1 Paul Bert, La pression barométrique: Recherches de physiologie expérimentale, etc., Paris: G. Masson, 1878.

The online version of this article is published within an Open Access environment subject to the conditions of the Creative Commons Attribution-NonCommercial-ShareAlike licence < http://creativecommons.org/licenses/by-nc-sa/3.0/ > . The written permission of Cambridge University Press must be obtained for commercial re-use. 
colleagues and porters to die on the mountainside - although by the time he wrote up his trip to ' $8840 \mathrm{~m}$ above sea level' two collaborators, Joseph Crocé-Spinelli and Théodore Sivel, had died due to hypoxia in the Zenith balloon flight of 15 April $1875 .^{2}$

And yet, if we dismiss Bert's claims to knowledge, and those like them, we are left in an awkward position. We knew nothing at all about the human body on the summit of Everest for another seventy-five years after Bert, when Hilary and Tenzing successfully climbed the mountain. It took over a century for systematic studies to be carried out there, when in 1981 the American Medical Research Expedition to Everest succeeded in taking a few clinical measurements on and very near the mountaintop. ${ }^{3}$ We knew nothing in this clinical sense about the female body on Everest for over a 130 years; that is, until 2007, when the Caudwell Xtreme Everest Expedition tested a mixed-sex party of research subjects within a few hundred metres of the summit. We remain entirely ignorant about the experiences of sparrows.

The great majority of what passes for our empirical knowledge about the experiences of the human body at the top of Everest has not been produced on or even close to the mountain's summit. Until 1981 what we knew about respiration and blood chemistry in Everest's 'death zone' was based on anecdotal accounts, studies at lower altitudes, extrapolations from mathematical models, and a fairly limited number of studies conducted, like Bert's, inside barometric chambers. And this mass of data is subject to immediate modification or dismissal when new knowledge is made on the mountain itself, even if that knowledge is created by non-scientists. In April 1978, mathematical models of thirty years' standing proved that man could not climb Everest without oxygen; in May 1978 an Italian explorer and an Austrian mountaineer overturned this model using their own, embodied, expert knowledge.

The philosophical challenge of experimental modelling, or re-creating or replicating nature in the laboratory, is by no means a new puzzle for the history of science. But it is possible to provide new insights by examining how the top of the world's tallest mountain has been modelled using the inside of a pressure chamber or the underside of a graph, and in particular by considering when and how this knowledge has been accepted or challenged by physiologists and mountaineers. In particular, it makes clear how much the specific identity of a natural space and the practical purpose of knowledge production can affect the viability and utility of models. It is one thing to 'know' what would happen to a man (or a sparrow) at the top of Everest in order to understand respiratory physiology; it proves to be quite another to understand respiratory physiology well enough to put your man there, safely and efficiently, before any other nation's flag is planted on the summit.

The history of high-altitude respiratory physiology is one in which authority, knowledge and actors moved frequently between several different kinds of research site. Kohler's typology of the laboratory, the laboratory-field border and the

2 For consistency, I will be using metric measurements when discussing the heights of mountains.

3 Dr Raymond Greene had succeeded in taking alveolar air samples just over seven thousand metres above sea level on Everest in 1933, but this lies just outside the 'death zone'; this is a rather colloquial phrase used to indicate roughly the crucial 'last' thousand metres of the mountain. R. Greene, 'Observations on the composition of alveolar air on Everest, 1933', Journal of Physiology (1934) 82, pp. 481-485. 
uncontrolled field site can be useful here, mapping onto sea-level barometric chamber studies, mid- and high-altitude research facilities and the direct experience of mountaineers in the 'natural laboratory' of Everest's slopes. ${ }^{4}$ Contrary to many accounts of the history of biology and biomedicine in the twentieth century, this story is one of a rejection of a reductive, molecular approach, and a decentring of the laboratory as a site of knowledge production and authority. Usefully for the historian, because research on the mountain was both expensive and dangerous, scientists have had to explicitly discuss the advantages of travelling to the field rather than using safer, sea-level, models.

Paul Bert had claimed, in the late nineteenth century, that the laboratory's barometric chambers and vacuum pumps were the only way to produce sure and certain knowledge about the physiology of man at high altitude. This is to be expected, as Bert was a protégé of Claude Bernard, and was working through the great period of the laboratory revolution in medicine, where, as the traditional narrative goes, physiology 'made medicine scientific' ${ }^{5}$ Bert's studies disciplined reports from the field, and through his laboratory studies the truth value of claims made by sojourners at altitude could be decided. This unidirectional flow of verified facts out from the laboratory was not to last; by the middle of the twentieth century, if one really wanted to know about the physiology of a human being on Everest, one had to go there. Alternative models, created for the needs of aviation or disease physiology, were inappropriate for Everest (as inappropriate, in fact, as their technologies of artificial respiration proved to be for mountaineers).

But while the laboratory model could not stand for Everest, Everest could stand for other models. Knowledge produced on Everest became richer than that produced elsewhere. As it was a unique site, work on the mountain was the only way to 'know' the mountain, and yet the data produced here could also be extrapolated out into generalizable principles about respiratory function, applied to the foetus, the Olympian and the resident of the Intensive Care Unit. ${ }^{6}$ By the end of the twentieth century a complex system of research, which I can only gesture to here, had been developed in altitude physiology: best understood as a form of 'staging', studies are first undertaken in the laboratory, then at altitude in colonized field sites such as research huts in the Alps, and then finally in research stations and 'wild' on Everest itself. At each stage unpromising research is weeded out, and the technology of experiment developed.

4 Robert E. Kohler, Landscapes and Labscapes: Exploring the Lab-Field Border in Biology, Chicago: University of Chicago Press, 2002.

5 W.F. Bynum, Science and the Practice of Medicine in the Nineteenth Century, Cambridge: Cambridge University Press, 1994; Andrew Cunningham and Perry Williams (eds.), The Laboratory Revolution in Medicine, Cambridge: Cambridge University Press, 1992.

6 For animal foetuses and human babies see Robert F. Grover, 'Failing hearts at high altitude', in John T. Reeves and Robert F. Grover (eds.), Attitudes on Altitude: Pioneers of Medical Research in Colorado's High Mountains, Colorado: University Press of Colorado, 2001, pp. 1-24; and Lorna Grindlay Moore, 'Small babies among big mountains', in Reeves and Grover, op. cit., pp. 137-160. For the Olympian see Vanessa Heggie, "Only the British appear to be making a fuss": the science of success and the myth of amateurism at the Mexico Olympiad, 1968', Sport in History (2008) 28, pp. 213-255. For ICU patients see Mike Grocott, Alan Richardson, Hugh Montgomery and Monty Mythen, 'Caudwell Xtreme Everest: a field study of human adaptation to hypoxia', Critical Care (2007) 11, p. 151. 
I am not attempting here to rewrite the history of respiratory physiology; on the contrary I am extremely grateful that a solid history of high-altitude physiology and mountaineering already exists as a basic frame for my work. ${ }^{7}$ Instead I will focus on a specific issue, the question of the role of supplemental oxygen in mountaineering above eight thousand metres. This was a great controversy, debated for over a century from the publication of Bert's major work in 1878 to Messner and Habeler's oxygenless ascent of Everest in 1978. The use of oxygen threw up both theoretical and practical challenges, and was heavily coloured by political and social attitudes towards sporting and scientific conduct; it was also an area in which the purpose of research - for aviation, medicine, climbing - significantly affected its conclusions. Most dramatically, it was also an area of research where the use of laboratory-generated standard models produced deeply misleading conclusions about the embodied human experience of the natural world.

\section{8: the ghastly kitchen}

Paul Bert was born in 1833, the son of a lawyer in Auxerre. Following in his father's footsteps he studied law in Paris, but converted to medicine and the natural sciences, gaining his medical license in 1860 and a doctorate in medicine in 1863. Claude Bernard, the 'father' of French experimental physiology, was one of Bert's doctoral examiners, and subsequently offered him a research position; Bert went on to gain a doctorate in natural sciences in 1865, winning the Académie des science's prize in experimental physiology. ${ }^{8}$ After briefly working as the professor of zoology in Bordeaux, Bert returned to teach physiology in Paris, inheriting Bernard's chair in physiology at the Sorbonne in 1869 . He was politically active, gaining a seat on the Paris Assembly in 1874, and elected to the Chamber of Deputies in 1876 - lending his support to Léon Gambetta, who appointed him minister for education and religion (1881-1882). Bert died aged fifty-three after a bout of dysentery in Hanoi, where he had been sent as the resident-general of the French protectorate in Vietnam.

Much of Bert's research was conducted in the 1870s before his political career became overwhelming. In the preface to La pression barométrique, first published in 1878 , he

7 The 'bible' for the history of high-altitude physiology is John B. West, High Life: A History of HighAltitude Physiology and Medicine, New York: Published for the American Physiological Society by Oxford University Press, 1998. This can be usefully supplemented with work by Kellogg and Rodway: R.H. Kellogg, “"La pression barométrique”: Paul Bert's hypoxia theory and its critics', Respiration Physiology (1978) 34, pp. 1-28; George W. Rodway, 'Prelude to Everest: Alexander M. Kellas and the 1920 high altitude scientific expedition to Kamet', High Altitude Medicine \& Biology (2004) 5, pp. 364-379; Rodway, 'George Ingle Finch and the Mount Everest expedition of 1922: breaching the 8000-m barrier', High Altitude Medicine 6 Biology, (2007) 8, pp. 68-76; Rodway, 'Ulrich C. Luft and physiology on Nanga Parbat: the winds of war', High Altitude Medicine \& Biology (2009) 10, pp. 89-96. The secondary literature on mountaineering is vast, but here I have made particular use of Walt Unsworth, Everest: The Mountaineering History, 3rd edn, London: Baton Wicks, 2000; and Maurice Isserman and Stewart Weaver, Fallen Giants: A History of Himalayan Mountaineering from the Age of Empire to the Age of Extremes, New Haven: Yale University Press, 2008. For a history of the technology of climbing, see Mike Parsons and Mary B. Rose, Invisible on Everest: Innovation and the Gear Makers, Philadelphia: Northern Liberties Press, 2003.

8 Kellogg, op. cit. (7), p. 5. 
makes it clear that this is a long-overdue assemblage of work to date, which has been delayed by his civic and political activities. ${ }^{9}$ This work has become a touchstone for high-altitude respiratory physiology, celebrated as the first detailed and systematic laboratory-based study of increased and diminished air pressure. Bert explored the roles played by different gases at varying pressures, experimenting on sparrows, rats, cats, dogs, frogs, rabbits and human volunteers, as well as discussing the effect of barometric pressure changes on the vegetable kingdom, inanimate matter and even microorganisms.

La pression does double ideological work, both proving a scientific 'fact' and also making a point about the centrality of the laboratory to medicine. ${ }^{10}$ It is therefore crucial to recognize La pression's place in a medical as well as physiological canon: although Bert was never a practising physician, this work is at its core a medical text, inspired by and dedicated to Dr Denis Jourdanet, who had not only suggested that Bert should investigate mal des montagnes but also substantially funded the high-cost laboratory equipment required. ${ }^{11}$ Bert was not tackling an abstract question about gases or respiration, but a specific and puzzling (and militarily important) heterogeneous disease entity, which produced different symptoms in different individuals at different heights.

Bert sought to discipline this disease, and so his conclusions, framed as a matter of the disturbance of bodily homeostasis, are perfectly in tune with the new French experimental physiology. Mal des montagnes is caused by a reaction of, to use the phrase coined by Bernard, the milieu intérieur to an abnormal environment; therefore it is only by isolating the specific disruption - which can be done most effectively in the laboratory - that the functions of the body can be understood. There were plenty of clinical observations, case studies and anecdotes about the disease, but what Bert strove to provide was the first 'purely experimental solution to these great problems' ${ }^{12}$ Bert's book starts with a 'Historique' section, where he painstakingly gathers the earlier stories and accounts - even those he dismisses as inaccurate - discussing the geography, ecology, geology and climate of various high-altitude regions as well as sickness in the mountains. This encompasses stories of 'headache mountains' from travellers in China around 30 BCE through to Robert Boyle's work on barometric pressure, Alexander von Humboldt's travels, and nineteenth-century alpinists' tales. Clearly there is some relationship between laboratory and field, with the observations and theories of climbers and explorers providing problems and assertions that the laboratory has to explain and evaluate. This relationship is, however, deeply asymmetrical, as it is the explanation provided by the laboratory which is used to determine which field observations are accurate; in other words, when laboratory experiment and field observation or travellers' account vary, it is the latter which err, not the former. Bert also uses the 'Historique'

9 Bert, op. cit. (1), p. v.

10 It also reflects Bert's anti-clericalism, as his dismissal of 'folk tales' about mountain sickness mirrors his critique of what he considered the superstitious beliefs of some branches of Catholicism. Kellogg, op. cit. (7).

11 Jourdanet had been part of the Mexican Scientific Commission sent by Napoleon III in 1864, an essentially military venture during the French intervention in Mexico; adaptation to altitude was a question crucial to the successful founding of strategic high-altitude bases. Philipp Felsch, Laborlandschaften: Physiologische Alpenreisen im 19. Jahrhundert, Göttingen: Wallstein Verlag, 2009, pp. 61-62.

12 Bert, op. cit. (1), p. iii: 'et de résoudre par voie purement expérementale ces importants problèmes'. 
section to consider existing explanations for mal des montagnes, dismissing all but the theory that the central clinically relevant feature of the disease is low oxygen content in the arterial blood - that is, Jourdanet's theory.

The most popular explanations for mountain sickness involved either the gaseous content or the 'weight' of mountain air. Bert's celebrated - and novel - achievement was to find a way to systematically relate both of those features to symptoms (and eventual death). This he did by exposing a range of animals (and people) to high and low pressures in barometric chambers and glass bells attached to vacuum pumps, while controlling the gas mixture they breathed (supplemented with studies of blood gas content, pulse, respiration rate and so on). The crucial measure, Bert claimed, was the partial pressure of oxygen $\left(\mathrm{PO}_{2}\right)$ - that is, the concentration of oxygen in the atmosphere moderated by the atmospheric pressure. It is not the proportion of oxygen which changes as one climbs a mountain, but, roughly speaking, the absolute amount of oxygen available per breath - as the air pressure falls, so does the density of the air. Bert demonstrated that when he used supplemental oxygen to compensate for low air pressure sparrows no longer vomited, rats did not asphyxiate, and he was able to 'climb' to the summit of Everest (which he approximated at $248 \mathrm{mmHg}$ pressure). ${ }^{13}$

A single, simple cause - a single disruptive environmental factor - which led to altitude sickness had implications for general studies of respiratory physiology and lung disease, but it also had a direct consequence for the practice of mountaineering. Bert himself explicitly linked his studies in the barometric chamber to the future practice of climbing. In the closing section of the book Bert considers the new technology of the self-contained pressurized oxygen tank, and, pointing out that he had himself been as 'high' as Everest's summit, concludes that the mountain could be climbed by man ('du mont Everest, la plus élevée des montagnes du globe $\left(8840^{\mathrm{m}}\right)$, n’est plus théoretiquement inaccessible à homme') provided he could have access to supplemental oxygen. ${ }^{14}$ The qualifier 'théoretiquement' is crucial here; Everest and its approaches lay in the territory of Tibet and Nepal, closed to European travellers, while around the mountain the 'Great Game' of espionage, mapping and exploration was being played out. ${ }^{15}$ Nonetheless, Bert is making strong claims for the equivalence of the chamber and the mountain, and is talking about climbing the mountain a decade or so before the more famous speculations by explorers such as Younghusband made the mountain a crucial destination for British climbers. ${ }^{16}$

While contemporary writers still cite Bert's stripped-down, single-cause, singlesolution model as the birth of high-altitude physiology, the laboratory-only model of

13 The first measurement taken on the summit in 1981 gave a value of 253 torr, which is approximately equal to $253 \mathrm{mmHg}$; these measurements can vary with the weather (see below). J.B. West et al., 'Barometric pressures at extreme altitudes on Mt. Everest: physiological significance', Journal of Applied Physiology (1983) 54, pp. 1188-1194.

14 Bert, op. cit. (1), p. 1105.

15 For a general history, see Isserman and Weaver, op. cit. (7). On pundits and mapping in particular see Kapil Raj, 'When human travellers become instruments', in Marie-Noëlle Bourguet, Christian Licoppe and Heinz Otto Sibum (eds.), Instruments, Travel and Science, London: Routledge, 2002, pp. 158-188.

16 For the 'early' discussion (i.e. pre-1900) of an attempt on Everest see Unsworth, op. cit. (7), pp. 11-12. 
explanation was to be the exception rather than the rule for this form of physiology. As soon as Bert made his work public his relentless focus on the laboratory was criticized, and his conclusions questioned. Bert made presentations to the Académie des sciences, which became a dozen short articles in a series in the Comptes rendues de l'Académie des sciences between 1871 and 1874. ${ }^{17}$ The first contradiction came from M. Dufour, president of the Société médicale de la Suisse romande, who had previously suggested that mountain sickness was caused by muscle fatigue. ${ }^{18}$ Although, as Kellogg has pointed out, when Dufour was made aware of Bert's studies he did alter his position to include 'facts' from the laboratory, he maintained that Bert's could never be the complete answer. Why? Because it was impossible to study mountain sickness in the barometric chamber. Dufour redefined mountain sickness as a combination of fatigue sickness and altitude sickness, i.e. a consequence of both the physical experience of climbing and the rarefied air. ${ }^{19}$

\section{The physiological 'observatory' goes high}

This criticism of experiment could be partially solved by relocating the laboratory. Towards the end of the nineteenth century a series of mid- and high-altitude research sites were constructed, often combining physiological research with astronomical observations (Figure 1). Although observatories have attracted some academic attention, a full discussion of the nature and variety of high-altitude laboratories remains to be written. ${ }^{20}$ Some are little more than a climbers' refuge, which for reasons of access, geography and politics sat within communication networks which made them ideal for scientific research. ${ }^{21}$ Others are virtual relocations of sea-level laboratory facilities. These are clearly field sites, because all experimenters and visitors are subject to the environmental disruption of low oxygen partial pressure; 22 on the other hand they are

17 Kellogg, op. cit. (7).

18 M. Dufour, 'Sur les mal des montagnes', Bulletin de la Société médicale de la Suisse romande (1874) 8, pp. 72-79.

19 Quoted in Bert, op. cit. (1), p. 1047.

20 On observatories see the special edition of Science in Context (2009) 22, particularly Deborah R. Coen, 'The storm lab: meteorology in the Austrian Alps', pp. 463-486, and Stéphane Le Gars and David Aubin, 'The elusive placelessness of the Mont-Blanc Observatory (1893-1909)', pp. 509-531. For context on the astronomical observatories see David Aubin, Charlotte Bigg and H. Otto Sibum (eds.), The Heavens on Earth: Observatories and Astronomy in Nineteenth-Century Culture, Durham: Duke University Press, 2010. For a view of high-altitude labs in the primary literature see Anon., 'A scientific laboratory two miles in the air', Popular Science Monthly, September 1917, p. 410. As a starting point for labs of other kinds, a 1954 UNESCO/US National Science Foundation-sponsored survey is particularly useful: Serge A. Korff (ed.), The World's High Altitude Research Stations, New York: New York University Press, 1954.

21 Catherine Nisbett Becker, 'Professionals on the peak', Science in Context (2009) 22, pp. 487-507.

22 It is notable that few (possibly none) of these high-altitude sites used systematic oxygen supplementation for researchers until the late twentieth century, despite the documented effects of hypoxia on close work and careful measurement. J.B. West, 'Oxygen enrichment of room air to relieve the hypoxia of high altitude', Respiration Physiology (1995) 99, pp. 225-232. Cf. the deep concern about the 'human factor' in astronomy in the nineteenth century: Jimena Canales, 'Exit the frog, enter the human: physiology and experimental psychology in nineteenth-century astronomy', BJHS (2001) 34, pp. 173-197; Simon Schaffer, 'Astronomers mark time: discipline and the personal equation', Science in Context (1988) 2, pp. 115-145. 


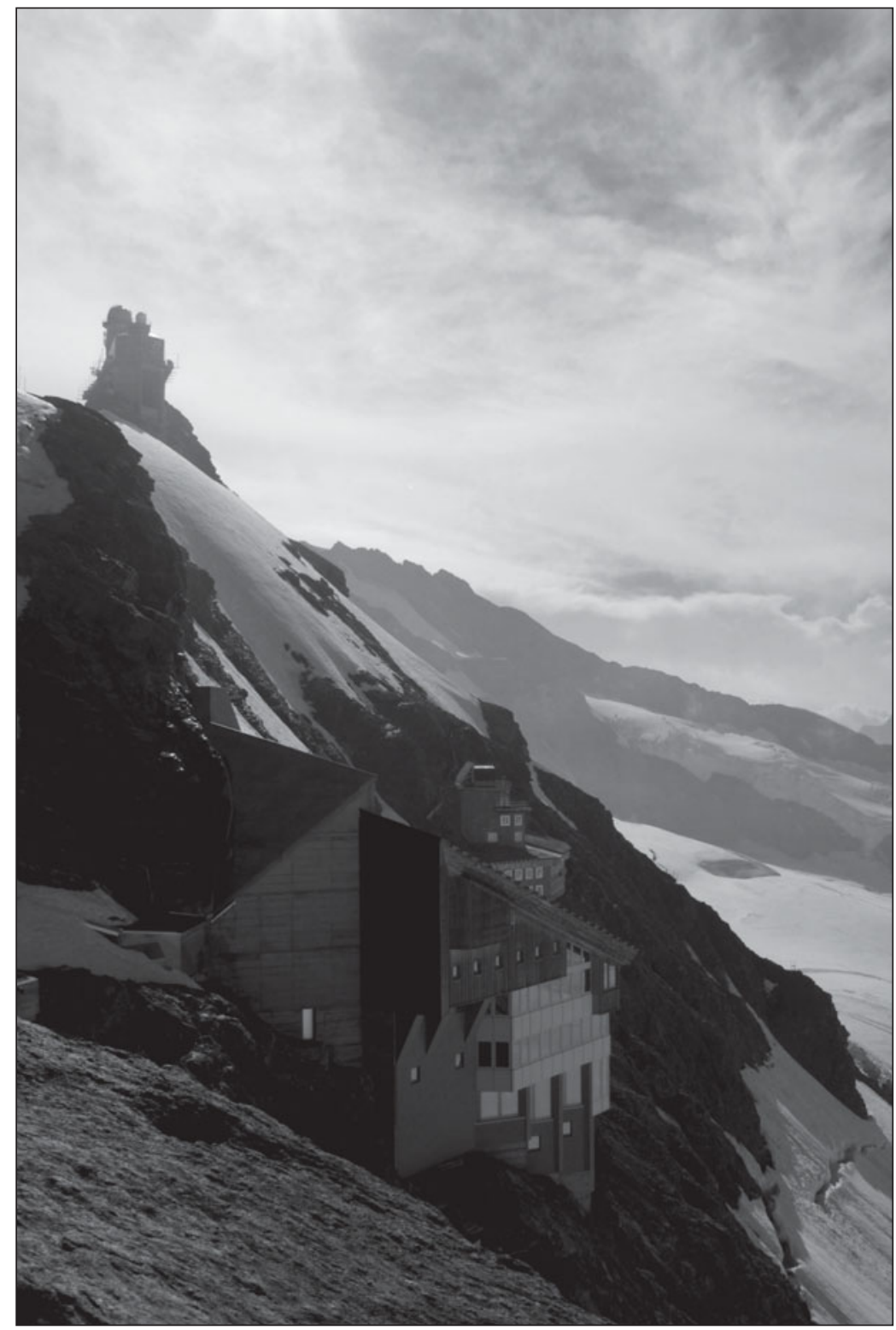

Figure 1. Research space on the Jungfrau, 2010. The Sphinx Observatory is to the top left, while some of the infrastructure (including extensive provision for tourists who travel up on the railway) is visible protruding from the rock below. This region of the Alps is also home to the Faulhorn hut, which was probably the first widely used research infrastructure at altitude (David Aubin, 'The hotel that became an observatory: Mount Faulhorn as singularity, microcosm, and macro-tool', Science in Context (2009) 22, pp. 365-386); it was also around the Jungfrau and its glacier that tests were done on the oxygen sets intended for the 1953 Everest expedition. Source: Mandeville Special Collections Library, University of California-San Diego, Box 39, Folder 2. (C) Ben Allen, 2010. 
clearly laboratory sites, which provide environmental control and communication systems, and act as single locations through which scientists, their experimental objects (human and animal), climbers, guides and instruments can pass.

In 1893 the Capanna Margherita, a climbers' shelter, was built on the Italian Alp Monta Rosa; with the addition of a basic laboratory space (often referred to as an 'observatory') in 1894 it became the highest laboratory in the world, and remains the highest such facility in Europe today. ${ }^{23}$ Its major user in these early years was Italian physiologist Angelo Mosso, who started his studies there in 1894 by taking a party of soldiers up to the hut to study fatigue and endurance. Mosso conducted hundreds of studies at and about altitude, many of which were published in his 1897 book Fisiologia dell'uomo sulle Alpi (translated in 1898 as Life of Man on the High Alps). ${ }^{24}$

Life of Man is a bricolage of subjects, styles and systems, and as such is symbolically representative of the web of research approaches and researchers who intersected at the liminal spaces provided by mountain laboratories. In comparison, La pression is a model of single-minded clarity - here there is a clear division between the historique collection of anecdotes, the descriptions and analysis of Bert's laboratory work, and the conclusion where he considers potential criticisms and others' work. Mosso's chapters combine, all in one place, anecdotes, his own experiments in laboratories (at sea level and at altitude) as well as on the mountainside, his personal experiences and those of colleagues, and a huge secondary literature. There is no single research question here; Mosso is interested, as the title suggests, in life as a holistic subject-studying the physique of the climber, diet and digestion, psychology, fatigue, ageing, respiration and racial and national differences in mountaineering ability.

Bert's was the first and the last book to be based entirely on the laboratory; for future generations of high-altitude physiologists it was Mosso's approach that would become the model. Indeed, Mosso's close connection to some of the most famous names in European physiology highlights the ease with which many researchers could moveintellectually if not physically - between experimental sites: laboratories, hospital clinics, mountains. ${ }^{25}$ Consequently, the celebration of Paul Bert as the founder of high-altitude physiology might seem puzzling; this can perhaps be explained by pointing out that for the more present-centred histories Mosso is problematic because he got it 'wrong', claiming carbon dioxide, not oxygen, as the crucial gas in the causation of mountain sickness.

Later writers have tried to explain Mosso's 'mistake' by criticizing his methods and his mathematics. ${ }^{26}$ But there was no inconsistency in his centralization of carbon dioxide. His own work in barometric chambers was confirmed by his studies on the mountainside - not least the story of Dr Etienne Jacottet, who died after a rapid ascent of

23 A. Cogo et al., 'Italian high-altitude laboratories: past and present', High Altitude Medicine \& Biology (2004) 1, pp. 137-147.

24 A. Mosso, Life of Man on the High Alps, 2nd edn (tr. E. Lough Kiesow), London: Taylor Unwin, 1898.

25 Mosso studied under Karl Ludwig, met Claude Bernard and Etienne Jules Marey on a visit to Paris, and hosted Nathan Zuntz in his laboratory.

26 Kellogg, op. cit. (7). 
Mont Blanc despite being given oxygen. ${ }^{27}$ Crucial here is the difference between oxygen use in the laboratory and on the mountain; in Mosso's work it is absolutely clear that the treatment of mountain sickness is the immediate, periodic application of oxygen, not the sustained, continual use we associate with climbing today. This difference - the controlled use of gas in the lab, and the difficult, impractical nature of oxygen transportation on the mountainside, remained a key difference between laboratory conclusions and field experience well into the twentieth century. And it was exactly this sort of fieldwork-studies of sustained use carried out by British and American researchers this time - which reinstated oxygen as the important gas in the early years of the twentieth century (see below). Mosso may have been mistaken in his conclusions about oxygen, but this did not undermine the value of his approach to the production of scientific knowledge. ${ }^{28}$

Mosso's attitude towards the truth value of 'facts' created in different locations seems complicated, but he consistently appears to favour the high-altitude fact over the fact created in sea-level laboratories. On comparing work done at 4,500 metres where experimental animals could thrive, and in barometric chambers where many died of 'fatty degeneration of the heart and other organs', he points out that 'the experiments performed under the pneumatic bell differ too widely from the life on the Alps to ensure reliable results'. ${ }^{29}$ As another example: Mosso suggests that fasting is not a bar to successful climbing as 'the tender [of the body] cannot be loaded only a few hours before the start, but must have its stores in readiness at least twenty-four hours before'. ${ }^{30}$ Oddly, Mosso makes no reference to his own laboratory studies on the dynamogenic properties of sugar, i.e. its ability to relieve muscular fatigue immediately, without loading a 'tender'. (Mosso's attempts to investigate the topic more systematically on the mountainside were 'interrupted by bad weather' and other studies. ${ }^{31}$ )

The book's readers certainly noticed the tension between laboratory and field, usually confirming Mosso's conviction that mountainside 'facts' trumped laboratory 'facts':

The modifications which are produced in the organism by residence at great heights differ in many respects from those witnessed in laboratory experiments... For this reason the observatories and huts on Mont Blanc and Monta Rosa have during the last few years afforded a shelter to several physiologists. ${ }^{32}$

'Several' is an understatement; a key feature of Mosso's work is the enormous network of researchers who pass through his research spaces - up mountains, at sea level, or as cuttings inserted into one of his chapters. Mid- and high-altitude research sites were places where like minds met, often hosting international and interdisciplinary groups. Mosso makes much use of the research of German physiologist and chemist Nathan Zuntz (whose work is particularly interesting here as he was the first researcher to point

27 For this and other examples of the uselessness of oxygen, see Chapter 13 in Mosso, op. cit. (24).

28 For more on Mosso's work in the broader European context see Felsch, op. cit. (11).

29 Mosso, op. cit. (24), p. 127.

30 Mosso, op. cit. (24), p. 118.

31 Mosso, op. cit. (24), p. 126

32 Anon., 'Book review: Life of Man on the High Alps', Nature (1899) 59, pp. 289-291, 289. 
out that equations used to map between barometric chamber pressures and 'real-world' altitudes were inaccurate). ${ }^{33}$ In turn, Zuntz organized a trip to the Pic du Midi on Tenerife in 1910 with, amongst others, two British researchers, Joseph Barcroft and C.G. Douglas. Subsequently, Douglas, J.S. Haldane and two physiologists from Yale-Yandell Henderson and Edward C. Schneider-spent five weeks of 1911 on Pikes Peak, Colorado on one of the most important field trips in respiratory physiology. This work reinstated Bert's oxygen hypothesis and involved the use of continuous supplies of oxygen whilst climbing. (The research party also included a woman, Mabel Fitzgerald, who conducted most of her pioneering research solo in the mining towns between 1,900 metres and 4,300 metres. ${ }^{34}$ )

The Pikes Peak publications do not specifically mention Everest - unlike both Bert and Mosso $^{35}$ - but the work done there produced theories and technologies which were central to (at least the British) expeditions. The choice of Pikes Peak was apparently due to Haldane, who particularly favoured a summit site with a railway line-partly for 'scientific' purposes as it allowed comparisons between people making rapid ascents and acclimatized visitors, but also because it saved the experimenters from having to climb, made equipment transport easier, and facilitated a better standard of living, as here an investigator did not have to 'cook for himself' - not all high-altitude physiologists have a passion for climbing. ${ }^{36}$ It is true that some of the work done here was overshadowed by the oxygen-secretion controversy-that is, the arguments that greeted Haldane's suggestion that passive diffusion of oxygen across the lung epithelium is replaced or supplemented by active transport in low $-\mathrm{PO}_{2}$ atmospheres - and academic rivalries about such proposals were to significantly affect the later expeditions to Everest. Nonetheless, Pikes Peak did produce knowledge and technology that was later to turn into practical, life-saving equipment. Both Haldane and Barcroft were also to become involved in the attempt to provide functional supplementary oxygen systems for the first attempts on the summit of Everest.

33 N. Zuntz, A. Loewy, F. Müller and W. Caspari, Hohenklima und Bergwanderungen in ibrer Wirkung auf den Menschen: Ergebnisse experimenteller Forschungen im Hochgebirge und Laboratorium, Berlin: Verlagshaus Bong, 1906. See also H.C. Gunga and K.A. Kirsch, 'Nathan Zuntz (1847-1920)', Aviation, Space, and Environmental Medicine (1995) 66, pp. 172-176; R.M. Forbes, 'Nathan Zuntz', Journal of Nutrition (1955) 57, pp. 1-15.

34 C. Gordon Douglas, J.S. Haldane, Yandell Henderson, Edward C. Schneider, Gerald B. Webb and J. Richards, 'Physiological observations made on Pike's Peak, Colorado, with special reference to adaptation to low barometric pressures', Philosophical Transactions of the Royal Society of London, Series B (1913) 203, pp. 185-318; D.B. Dill, 'Mabel Purefoy Fitzgerald-our second centenarian', The Physiologist (1973) 16, p. 247; Robert W. Torrance and John T. Reeves, 'Major breathing in minors: Mabel Purefoy Fitzgerald, an intrepid scientist, visits Colorado's high mines', in Reeves and Grover, op. cit. (6), pp. 59-86; Mabel Purefoy FitzGerald, 'The changes in the breathing and the blood at various high altitudes', Philosophical Transactions of the Royal Society of London, Series B (1913) 203, pp. 351-371.

35 Mosso spends several pages arguing that a Himalayan expedition is more necessary and just as noble as a polar exploration. Mosso, op. cit. (24), pp. 314-316.

36 West, op. cit. (7), p. 114. 


\section{Up Everest}

Around the time when Barcroft and Haldane returned from Pikes Peak, three events occurred which conspired to create an impetus for British expeditions to Everest. First, in 1910 the Italian soldier-explorer the Duke of the Abruzzi set a new altitude record on Chogolisa (7,943 metres), disproving the more conservative estimates of human altitude tolerance. Second, Tibetan independence, secured in part by British weaponry, meant that negotiations for British access to the mountain seemed more promising. ${ }^{37}$ Finally, and most poignantly for the British, in February 1913 the death of Robert Falcon Scott and his team was made public. British citizens had failed in their attempts to be first to the North Pole, and had died in their attempt on the South Pole; Everest, the 'third pole', was a last-chance exploratory first for a fading imperial nation.

While plans for a reconnaissance and summit attempt were being drawn up by the Royal Geographical Society (RGS) and the Alpine Club, it was a German-trained Scottish chemist who most clearly articulated the value of supplementary oxygen for an Everest expedition. Alexander Kellas presented papers to the RGS in 1916 and the Alpine Club in 1917 in which he suggested that the mountain was theoretically scalable without oxygen by 'a man in first-rate training, acclimatised to maximum possible altitude ... provided that the physical difficulties ... are not prohibitive'. ${ }^{38}$ Since no one knew how technically challenging Everest might be, Kellas maintained that oxygen technology should be investigated and taken by any future expeditions.

In 1920 Kellas went to India to trial commercially available oxygen tanks and masks. He was acutely aware of the differences between the experiences of climbers and 'armchair theorists' ${ }^{39}$ and a keen advocate of local knowledge and experience. ${ }^{40}$ His work is celebrated as proof of concept and an exceptional contribution to physiology, but was then unfortunately denigrated and ignored by subsequent expeditions. In fact the results of his studies were ambiguous; ${ }^{41}$ commercial tanks were not designed for active climbing and posed many functional challenges. ${ }^{42}$ While in India he received an invitation to participate in the first British expedition to Everest in 1921, but succumbed to a gastrointestinal complaint and died during the long march to the mountain. Despite the mixed results of his work, his death is mourned in some histories not just as the first fatality of British Himalayan ambition, but also as the loss of an oxygen advocate,

37 Unsworth, op. cit. (7), Chapter 1.

38 A.M. Kellas, 'A consideration of the possibility of ascending the loftier Himalaya', Geographical Journal (1917) 49, pp. 26-46, 46.

39 This was an insult used by German physiologist Guenter Dyhrenfurth to dismiss the work of Charlie Houston (see below); Dyhrenfurth also criticized the prevalent German scepticism of oxygen, which makes arguments about characteristically British sportsmanship retarding the use of oxygen hard to maintain. G. Dyhrenfurth, To the Third Pole: The History of the High Himalaya (tr. Hugh Merrick), London: Werner Laurie, 1955, p. 14.

40 Kellas was the first Westerner to recommend Sherpa guides. Rodway, 'Prelude to Everest', op. cit. (7), p. 365.

41 Even the pro-oxygen lobby critiqued Kellas's experiments for being conducted at too low an altitude to be of relevance to a summit dash on Everest. Memo from T.H. Somervell to Everest Committee, January 1922, Royal Geographical Society, Everest Papers (henceforth RGS/EP) EE38/4/10. George W. Rodway, George Ingle Finch's 'The Struggle for Everest', Trowbridge: Cromwell Press, 2008, p. 57.

42 Anon., 'Dr Kellas' Expedition to Kamet', Geographical Journal (1921) 57, pp. 124-130. 
without whom both respiratory physiology and British climbing were significantly retarded. 43

The desire to find reasons for the failures and tragedies of British expeditions in the 1920s and 1930s often finds its focus in the failure of technical expertise or the resistance of some team members towards oxygen. There is a conventional narrative which fits well with other stories about British sportsmanship and science, where the continued resistance of climbers to 'technological assistance' can either be celebrated as an expression of British gentlemanly amateurism and sporting spirit, or criticized as a naive rejection of technology and representative of British failure to support science and research. ${ }^{44}$ Neither interpretation adequately characterizes what was happening in altitude physiology, mountaineering or oxygen technology in the 1920s or 1930s.

In a sense, the oxygen dispute is tangential to the history of high-altitude respiration, as there was apparent consensus among most physiologists and interested climbers about what was expected to happen on the last crucial metres on Everest. Generally it was argued that human beings can probably acclimatize sufficiently to climb to the summit without oxygen - assuming (and this is a huge assumption) that the weather and other climbing conditions were favourable. ${ }^{45}$ At the same time, it was clear that oxygen would assist the climber as long as the delivery technology was appropriate. It was this criterion that was the focus of the dispute, not the utility of oxygen per se. If the harness and cylinders weighed too much, if the valves froze, if the masks were uncomfortable, the benefits of supplemental oxygen could disappear.

It is easy for retrospective accounts to take the advantages of oxygen as inarguable and 'known' since Bert's work, so that oxygen scepticism is represented as a conflict between a proven scientific fact and an unscientific climbing community. In fact, the results with oxygen were far more ambivalent. The 'fact' of the technology was that it was heavy and bulky, and the unfamiliar discomfort of the equipment did not recommend it for expeditions into the unknown; cylinders did not travel well and regularly leaked, crucial parts froze and broke, and a host of minor technical issues were not resolved until well into the $1950 \mathrm{~s} .{ }^{46}$ The rejection of oxygen technology could be both a sporting preference and a legitimate scientific response.

The oxygen dispute was therefore a debate about the relocation of technology, and should be studied as such. It is also a debate which encompasses larger scandals and

43 E.g. John West, 'Alexander M. Kellas and the physiological challenge of Mt. Everest', Journal of Applied Physiology (1987) 63, pp. 3-11.

44 For the bigger picture see David Edgerton, Science, Technology and the British Industrial 'Decline', 1870-1970, Cambridge: Cambridge University Press, 1996.

45 Anon., 'A new Mount Everest expedition', Geographical Journal (1932) 80, pp. 334-335; J.B. [J.S.] Haldane et al., 'Equipment for high altitude mountaineering, with special reference to climbing Mount Everest: discussion', Geographical Journal (1923) 61, pp. 199-207. See also suggestions of a change of consensus in 1914 in Douglas Freshfield, 'The conquest of Mount Everest', Geographical Journal (1924) 63, pp. 229-237.

46 As late as the Cho Oyu pre-Everest reconnaissance in 1951 Dr Pugh wrote, 'supplementary oxygen improved work rates considerably, but the effect was largely counterbalanced by the weight of the apparatus'. Pugh to Roxburgh, 16 September 1952, Mandeville Special Collections Library, University of California-San Diego. This is a special collection, gathered by John West, on high-altitude physiology; papers are divided by surname and will be referred to as Mandeville/Surname, e.g. Mandeville/Pugh, Box 33, Folder 1. 
long-running personal rivalries. ${ }^{47}$ This is not to suggest there was no sense of sportsmanship at stake in the debates: it is clear that most of the climbers on the expeditions of the 1920s and 1930s would have considered a climb without oxygen superior to one with oxygen. But this singling out of oxygen is inconsistent (as its supporters pointed out), as climbers happily used other technological and chemical assistance-indeed, Mallory himself wrote, 'Young Haldane professes to be able to recommend a stimulant similar to caffeen [sic] and kola, but much better and absolutely innocuous. I'll get in touch with him'. ${ }^{48}$ Some of the most important technical advances on the mountainside were imagined and practically enacted by dedicated amateur sportsman Andrew 'Sandy' Irvine. ${ }^{49}$

A closer reading of what is usually presented as an example of this 'ethical' debate demonstrates instead the extent to which the facts from the 'natural laboratory' of the mountain were prioritized over knowledge produced anywhere else. In 1922 A.R. Hinks, Cambridge-trained astronomer and geographer, and at the time the RGS representative on the Everest Committee (a joint committee of the Alpine Club and the RGS), wrote to the president of the Alpine Club,

I should be especially sorry if the oxygen outfit prevents them going as high as possible without it. The instructions laid down by Dreyer say ... that oxygen should be used continuously above $[7,000$ metres]. That ... is all nonsense ... If some of the party do not go to [7,600 metres] without oxygen they will be rotters. ${ }^{50}$

'Rotters' is regularly quoted to demonstrate the RGS's attitude towards the use of oxygen, ${ }^{51}$ but this is a misuse of Hinks's words. First, Hinks is saying nothing about the summit of Everest, at 8,848 metres, but referring to a height already reached without oxygen. ${ }^{52}$ Second, the reference to Dreyer is crucial, as this is Georges Dreyer, ${ }^{53}$ a physiologist whose experience was not based on mountaineering but on aviation (which, as the next section will show, is a poor model for climbing). Dreyer's extreme conservatism about human acclimatization was not accepted by the majority of expedition physiologists, doctors or mountaineers themselves. Criticism of Dreyer is

47 Georges Dreyer was one of a few physiologists who insisted on the necessity of oxygen on Everest, and his work influenced a 1922 Alpine Journal article on the topic which appeared critical of Kellas's work. But Dreyer had a long-standing rivalry with Haldane (as Younghusband put it, 'Dreyer is a scientific enemy of Haldane'), and, as Kellas had experimented with Haldane, an attack on one was an attack on the other, and was as much about the oxygen secretion debate as about Everest. Dreyer was an 'armchair theorist' and consequently, as Younghusband put it, 'we do not consider Dreyer the last word on the subject'. Younghusband to Bruce, 12 April 1922, RGS/EP EE1/18/1/55; P.J.H. Unna, 'Everest 1922 - oxygen equipment', Alpine Journal (1922) 34, pp. 235-242.

48 'Young Haldane' is almost certainly J.B.S. Haldane, who at this point had just taken up his readership in Biochemistry at Trinity College, Cambridge. Baldrey to Colonel Bruce, 22 November 1923, RGS/EP EE/22/1/8. 49 Rodway, op. cit. (41), p. 196.

50 Unsworth, op. cit. (41), p. 78. T.S. Blakeney, 'A.R. Hinks and the first Everest expedition, 1921', Geographical Journal (1970) 136, pp. 333-343.

51 E.g. Unsworth, op. cit. (7), Chapter 3 (heading); E. Simons and O. Oelz, 'Mont Blanc with oxygen: the first rotters', High Altitude Medicine \& Biology (2001) 2, pp. 545-549.

52 In fact Hinks followed the general Everest Committee line that if oxygen was necessary it should be used. Anon., 'The Mount Everest expedition', Geographical Journal (1922) 59, pp. 379-383, 381.

53 See note 47. Georges Dreyer is sometimes rendered as ‘George', e.g. in Rodway, 'George Ingle Finch', op. cit. (7). 
not criticism of oxygen - it is criticism of the 'armchair theorist', or the 'fact' not made on a mountain.

There were three British expeditions to Everest in the 1920s, culminating in the 1924 expedition which led to the deaths of Mallory and Irvine. Because of the fatalities, and some alleged transgressive behaviour of team members (namely rock collecting), the Dalai Lama subsequently declared Tibet closed to British explorers, and the mountain was not attempted again until the 1930s. In this decade, four expeditions were mounted-again under the joint direction of the Alpine Club and the RGS - with full attempts in 1933, 1936 and 1938, and a reconnaissance in 1935. These expeditions were remarkable failures, mostly due to unusually poor weather conditions, bad luck and some serious tensions between team members. All four expeditions took oxygen with them, and for the 1933 trip some important modifications were made to the packs by the expedition doctor, Raymond Greene, while a new respirator, designed in Cambridge, was refined using feedback from these and other expeditions. ${ }^{54}$ The teams of the $1930 \mathrm{~s}$ showed a more consistent belief that the mountain could be climbed without oxygen, and so less use was made of the sets taken (although experiments on the 1938 trip seemed to demonstrate the technology's value). ${ }^{55}$ Partly their attitude may have been meteorologically influenced; while the weather was bad for climbing, pressures were higher than normal, making breathing easier. ${ }^{56}$ Meanwhile, research into altitude physiology continued in laboratories at various altitudes, and in a series of high-altitude expeditions in South America. ${ }^{57}$

\section{Interlude: the distraction of aviation}

In the 1920s and 1930s oxygen was a potentially useful, but possibly non-essential, assistant technology for the mountaineer. By 1950 it seems to have become an absolute necessity; at least it was unthinkable that the next British expedition would plan for anything other than an oxygen-assisted summit attempt. ${ }^{58}$ It is also around this time that accounts of Everest expeditions and high-altitude physiology began to explicitly figure

54 This was the Matthews Respirator. Unsworth, op. cit. (7), p. 163. Matthews developed the respirator as a consequence of work done on the International High-Altitude Expedition to Chile in 1935, led by David Bruce Dill of the Harvard Fatigue Laboratory. West, op. cit. (7), p. 255.

55 Those involved in expeditions consistently claimed that part of their purpose was to produce new physiological knowledge: see RGS/EP EE/54/2. See also the same reference for an extremely balanced, but sadly anonymous, analysis of the state of the oxygen debate and evidence for its utility (which tentatively comes out in favour of planning for an oxygen-assisted summit attempt) titled 'The oxygen problem' and marked with the original reference code 42/8. Even when expeditions were designed as 'purely' mountaineering or 'resolutely' non-scientific, considerable research was often still conducted. See, for example, this account of work done on the 1936 expedition, which had no formal scientific programme: C.B. Warren, 'The medical and physiological aspects of the Mount Everest expeditions', Geographical Journal (1937) 90, pp. 126-143.

56 L.G.C.E. Pugh, 'The effects of oxygen on acclimatized men at high altitude', Proceedings of the Royal Society of London, Series B (1954) 143, pp. 14-17.

57 See note 54.

58 'It is now certain that it is a quite unjustified physiological risk to attempt to reach the summit without oxygen equipment'. Untitled report, probably by Pugh for the MRC High Altitude Committee or the Oxygen Sub-committee, n.d. (c. October 1952), Mandeville/Pugh, Box 36, Folder 8. 
the oxygen-scepticism of earlier decades as irrational and damaging to British interests. ${ }^{59}$ There seem to be two central reasons for this change, one pragmatic and political, the other to do with the sort of experiments and expertise generated during the Second World War.

In 1952 the Swiss were permitted by the Nepalese government to make not one but two attempts on Everest. With other nations lining up for access it became painfully clear that the window of opportunity to get a British climber to the top of Everest first was rapidly closing. The era when Everest could be considered a 'British' mountain (as Nanga Parbat had been 'German') was over. In previous years members of the RGS had suggested that an oxygenless ascent would be preferable, because if the British got there first with oxygen, there would be attempts by other nations to do it without gas - better by far for the British to finish the job once and for all. ${ }^{60}$ But, after thirty years, six full expeditions and dozens of fatalities, any sort of successful summit bid became acceptable.

There is a second reason for the changing status of oxygen, and that is the rise of aviation research, despite the fact that there is a strong disanalogy between the pilot and the mountaineer. Many of the physiologists involved with altitude studies made significant contributions to military research, such as Barcroft's work on poison gases, or Dreyer's research into oxygen technology for the Royal Air Force. ${ }^{61}$ While a great deal of this work was directly useful to mountaineering, the study of aviation medicine in particular poses fundamentally different questions than does the study of mountain physiology. The role of fatigue was still a complicating factor in the analysis of mountain sickness, while the major difference between the pilot and the climber is that of acclimatization. Acclimatization takes place over many weeks and significantly alters human physiological processes, changing breathing rates, the concentration of red blood cells in the blood and even the affinity of haemoglobin for oxygen. Researchers since Bert had suggested that slow ascents were safer than fast ones, and mountain railways and balloon ascents were used to study the processes of acclimatization comparatively.

Ironically, then, it was an attempt to replicate acclimatization in the barometric chamber which produced the first serious challenge to the notion that man could climb Everest without oxygen. In 1933 Charles ('Charlie') Houston, an American physiologist and enthusiastic mountaineer, secured money from the US Naval Research Programme

59 Dyhrenfurth, op. cit. (39); L.G.C.E. Pugh and M. Ward, 'Appendix VIII: physiology \& medicine', in John Hunt, The Ascent of Everest, London: Hodder \& Stoughton, 1953, pp. 270-279.

60 For example, Raymond Greene: 'the business of getting up Everest will not be finally settled until somebody has got up without oxygen', in Kenneth Mason et al., 'The Mount Everest expedition of 1938: discussion', Geographical Journal (1932) 92, pp. 490-498. Greene was generally in favour of the use of oxygen, but this view coincides with that of those who were not, e.g. Tilman: 'my feeling is that a successful oxygen attempt would merely inspire a wish to do it without.' H.W. Tilman, 'The Mount Everest expedition of 1938', Geographical Journal (1938) 92, pp. 481-490.

61 Steve Sturdy, 'From the trenches to the hospitals at home: physiologists, clinicians and oxygen therapy, 1914-30', in John V. Pickstone (ed.), Medical Innovations in Historical Perspective, London: Palgrave Macmillan, 1992, pp. 104-123. 
for a project named 'Operation Everest'. ${ }^{62}$ Houston drew on his own mountain experience in an attempt to model as closely as possible a mountain ascent, hoping that lessons from mountaineering could be made relevant for aviation. The 'ascent profile' he designed was intended to mimic the climbing pace up a Himalayan peak, including a series of 'rushes for the top' on the twenty-ninth to thirty-second days. This was probably the most epic barometric chamber experiment ever attempted, and yet the subjects 'did not acclimatize to altitude as completely or rapidly as do mountaineers', highlighting the limitations of barometric chamber studies. ${ }^{63}$ The practicality of keeping military personnel for weeks in a cramped chamber (or, indeed, sending them up a Himalayan mountain) was doubtful, and the conditions difficult - the $7 \times 7 \times 10$-foot chamber was crowded with beds and equipment, and shared by four male subjects for thirty-five days; only allowed to bathe every other day, two of the subjects smoked cigarettes throughout the experiment.

Yet the experiment produced a 'fact' apparently of relevance to mountaineering. At 8,848 metres above sea level two of the participants had to take supplemental oxygen just to stay conscious, while the other two could only cope with the conditions if they were in complete repose. There was absolutely no question of easy climbing, let alone a challenging ascent; Everest could not be climbed without oxygen. That fact seems hard to square with subsequent events, and (aside from issues of acclimatization) there is an immediate explanation: the International Civil Aviation Authority's standard atmosphere. Designed in 1924 for the calibration of aircraft altimeters, the standard atmosphere is based on estimated 'mean' atmospheric conditions. ${ }^{64}$ The Earth's atmosphere is actually thinner at the poles, thickening towards the equator, so that an Everest located near, say, the Sorbonne in France would have lower barometric pressure and oxygen partial pressure at its summit than the Everest located in the Himalaya. When Operation Everest's researchers converted from pressure to altitude they underestimated the equivalent height on 'Himalayan Everest'; the chamber's residents had in fact experienced a barometric pressure one might expect to find about 180 metres above the summit of Everest. ${ }^{65}$

Altitude above sea level and barometric pressure are not equivalent metrics, and their inter-conversion is deeply contingent upon the precise geographical and environmental situation of a mountain. This fact has been realized and re-realized by physiologists at least since Zuntz's work on a conversion equation in $1906 .{ }^{66}$ In 1935 Haldane and Priestly suggested in their textbook Respiration that barometric pressures calculated using Zuntz's formula significantly deviated from those calculated according to the

62 Charles S. Houston, 'Operation Everest: a study of acclimatization to anoxia', US Naval Medical Bulletin (1946) 46, pp. 1783-1792.

63 Houston, op. cit. (62), as quoted in Abstracts, Anaesthesiology (1947) 8, pp. 442-443, 443.

64 There are now dozens of 'standard atmospheres' in use. See American Institute of Aeronautics and Astronautics, Guide to Reference and Standard Atmosphere Models, 2004, ANSI/AIAA G-003B-2004.

65 L.G.C.E. Pugh, 'Resting ventilation and alveolar air on Mount Everest', Journal of Physiology (1957) 135, pp. 590-610, 604-605.

66 Zuntz, op. cit. (33). 
formulas used to calibrate altimeters. ${ }^{67}$ The relationship between pressure and altitude remained problematic for researchers trying to map between the chamber and the mountain; despite a plea to 'Report Barometric Pressure!' in the Journal of Applied Physiology in 1970, the two measurements continued to be confused and conflated. ${ }^{68}$ Even by the end of the twentieth century only a handful of pressure measurements had been made on Everest's summit and perhaps a few dozen at similar altitudes on neighbouring mountains or in weather balloons. ${ }^{69}$ These readings vary significantly with the weather conditions, from around 251 torr in the popular climbing months of May and October, up to 255 in midsummer, with the lowest midwinter measure 243 torr. To give a sense of scale (having said that altitude and pressure are not strictly interchangeable): if 251 torr is 8,848 metres, then the 'height' of the summit varies from around 8,700 metres to around 9,000 metres above sea-level.

Extrapolating from aviation to mountaineering had been problematic in the 1930s for British expeditions - for example, Dreyer's worries that a failure in the oxygen system at altitude might lead to immediate unconsciousness was a real concern for aviators, but much less so for acclimatized mountaineers. ${ }^{70}$ But in the 1950s the debate over oxygen use rarely discussed the absolute possibility of breathing at 8,848 metres, or the risk of collapse, but rather the possibility of mental impairment. Stories about the mental effects of high altitude are long-standing, and high-altitude expeditions of the early twentieth century produced some striking examples. The mental impairment of pilots was a pressing concern for military operations, and it appears that it is this issue which really fixed oxygen as a necessity for the last thousand metres on Everest. ${ }^{71}$

In 1947, in the first major consideration of the oxygen requirements of an Everest attempt since the 1930s, Wing Commander H.L. Roxburgh of the RAF's Institute of Aviation Medicine wrote in the Geographical Journal, 'To climb Everest without oxygen ... would be like climbing an equally difficult and dangerous but much lower slope in a state of alcoholic intoxication... A man who could climb Everest without oxygen and survive would be physically and mentally exceptional and also remarkably lucky. ${ }^{72}$ Neither the RGS nor the Alpine Club was willing to leave a successful climb to luck this time. When preparations were made for the 1953 expedition Roxburgh was coopted onto an 'Oxygen Sub-Committee' which meticulously researched,

67 The deviation becomes noticeable around 4,500 metres. J.S. Haldane and J.G. Priestly, Respiration, Oxford: Clarendon, 1935.

68 D.B. Dill and D.S. Evans, 'Report barometric pressure!', Journal of Applied Physiology (1970) 29, pp. 914-916.

69 J.B. West, 'Barometric pressures on Mt. Everest', Journal of Applied Physiology (1999) 86, pp. 1062-1066.

70 See also note 47 above.

71 This was particularly illustrated by deteriorating handwriting and the inability to write series of numbers at simulated (or real) altitudes. Phillippe Felsch, 'Mountains of sublimity, mountains of fatigue: towards a history of speechlessness in the Alps', Science in Context (2009) 22, pp. 341-644; Christian Kehrt, "Higher, always higher": technology, the military and aviation medicine during the age of the two world wars', Endeavour (2006) 30, pp. 138-143. But see note 22 above, on astronomers and low-oxygen environments.

72 H.L. Roxburgh, 'Oxygen equipment for climbing Mount Everest', Geographical Journal (1947) 109, pp. 207-216, 208. 
redesigned and recalculated the oxygen supply that would be required to reach the top of Everest.

\section{On Everest}

In 1951 the surgeon Michael Ward sparked the revival of coordinated British attempts on the Third Pole. ${ }^{73}$ His success in rousing the interest of the Himalayan Committee, ${ }^{74}$ which has been considering but not organizing expeditions since 1945, was probably due to his recruitment of prominent supporters from within the climbing community. ${ }^{75}$ The physiologist Charlie Houston and the one-time leader of British expeditions Bill Tilman had explored the Everest region in 1950 with an Anglo-American team, producing an ambiguous report about new routes to the summit. Consequently a small British reconnaissance party was sent out in 1951, which proposed a new route up Everest using an approach from the south. ${ }^{76}$ The fact that the Swiss were granted both pre- and post-monsoon access to Everest was a serious blow to the Himalayan Committee, who instead arranged to send a research team to Cho Oyu, an unclimbed mountain over eight thousand metres tall and some twenty kilometres west of Everest.

The research team consisted of ten men, eight experienced climbers (including Edmund Hillary), climber and oxygen expert Tom Bourdillon and physiologist Lewis Griffith Cresswell Evans Pugh. ${ }^{77}$ Pugh had developed an interest in human physiology in extreme environments through work with military ski teams and a naval arctic expedition. $^{78}$ On Cho Oyu he conducted extensive tests of oxygen, and further physiological research into adaptation, fatigue, exercise and diet. Together the team refined the technology of oxygen supplementation, changing masks, valves, harnesses and the gas's flow rate. ${ }^{79}$ Meanwhile the Swiss team failed in both its attempts to reach

73 Ward identified covert aerial surveillance photos in the RGS archives and combined these with various maps and plans to draw up a new, feasible, route to the summit of Everest via the Western Cwm. Michael Ward, Everest: A Thousand Years of Exploration, Glasgow: Ernest, 2003; George W. Rodway and Jeremy S. Windsor, 'Pioneer of the high realm: Michael Ward's life of medicine, mountaineering and exploration', Wilderness and Environmental Medicine (2008) 19, p. 52. As early as 1918 Kellas had given the RGS a presentation on the value of aerial reconnaissance: A. Kellas, 'The possibility of aerial reconnaissance in the Himalaya', Geographical Journal (1918) 51, pp. 374-382.

74 This was the reconstituted Everest Committee, still a collaboration between the RGS and the Alpine Club, although now with a slightly broader remit.

75 Isserman and Weaver, op. cit. (7), p. 262.

76 This party was led by Eric Shipton, and included the New Zealanders Eric Riddiford and Edmund Hillary, as well as Ward and the oxygen expert Tom Bourdillon.

77 Pugh's leading place on this team was funded by the Royal Society; $£ 600$ was paid to allow him to be 'attached' to the 1951 expedition. L.P. Kirwan to Pugh, 22 November 1951, Mandeville/Pugh, Box 33, Folder 1.

78 I would like to thank Harriet Tuckey, Dr Pugh's daughter, for providing me with material from her forthcoming biography of Dr Pugh.

79 For a general report on the expedition see Eric Shipton, 'The expedition to Cho Oyu', Geographical Journal (1953) 119, pp. 129-137. 
the summit of Everest, an outcome sometimes put down to dehydration, but more often attributed to a failure of their oxygen equipment. ${ }^{80}$

Colonel John Hunt was picked to lead the 1953 Everest Expedition; his military-style organization with a large team was now favoured over the 'alpine-style' small, light assaults of previous leaders like Eric Shipton. Although subsequent analyses give much credit to Hunt's style of climb, he clearly thought their success was due to oxygen: 'only [oxygen], in my opinion, was vital to success... But for oxygen, without the much improved equipment which we were given, we should certainly not have got to the top'. ${ }^{81}$ Tenzing and Hillary's successful summit ascent on 29 May 1953 was actually the second attempt, as Bourdillion and Charles Evans had been given the first opportunity to reach the summit using the favoured closed-circuit oxygen system; the second team, in open-circuit equipment, succeeded in part because of canny oxygen caching by the first team. ${ }^{82}$

1953 was proof of concept; in their various ways Bert, Kellas and others had been vindicated, as supplemental oxygen certainly could enable a successful climb of Everest. But most crucial to the success was not the laboratory work of Bert and other physiologists in their 'diabolical chambers', ${ }^{83}$ but rather the fieldwork done deliberately by Barcroft, Kellas, Finch, Greene, Pugh and others, and done by accident and by necessity by two generations of high-altitude mountaineers. As the Swiss failure was framed as a failure of the oxygen systems, it seems natural to frame the British success as a consequence of technological superiority. Indeed, much of Hunt's The Ascent of Everest is given over to accounts of the technical apparatus the team used-although there are easily as many anecdotes about frozen valves and leaking cylinders as there are about successful use of the equipment. For good or bad, oxygen looms extremely large in Hunt's account, which also contains meticulous appendices on the other technology used, including tents, dietary rations and so on. Despite this emphasis, the success of 1953 has been made to do double work in subsequent accounts, and there has been a tendency, at least in popular historiography, to 'forget' the technical achievements - a pattern also highlighted by Max Jones with regard to polar expeditions. ${ }^{84}$ On the one hand the successful 'conquest' of Everest was a scientific and technical triumph and was celebrated in the popular media as such. On the other hand all the Everest teams,

80 John B. West, 'Failure on Everest: the oxygen equipment of the spring 1952 Swiss expedition', High Altitude Medicine \& Biology (2003) 4, pp. 39-43; René Dittert, Gabriel Chevalley and Raymond Lambert, Forerunners to Everest, London: Hamilton \& Co., 1956.

81 Hunt, op. cit. (59), p. 228.

82 Closed-circuit systems 'recycle' exhaled air by passing it through a chemical filter which removes excess carbon dioxide, making them more efficient than open-circuit systems where up to 90 per cent of the oxygen inhaled is not used by the body, but lost on exhalation. 'Report of Dr Pugh's discussion at Dr Shipton's lecture at the RGS', 24 April 1953, Mandeville/Pugh, Box 33, Folder 1; see also Mandeville/Hornbein, Box 31, Folder 6.

83 G. Mallory, 'The first high climb', Geographical Journal (1922) 60, pp. 400-412, 410.

84 Max Jones, The Last Great Quest: Captain Scott's Antarctic Sacrifice, Oxford: Oxford University Press, 2003. 
Hunt's included, are as frequently represented as tweed-wearing gentlemen amateurs as they are as experienced, highly equipped experts. ${ }^{85}$

The story of amateur British climbers who triumph with what appears to be basic equipment holds a continuous appeal, and the process of dismissing past scientific achievements on Everest seems to start in earnest as early as 1953. Pugh and Ward's assessment of previous British attempts on Everest is brutal, and inaccurate:

the futile controversy over the ethics of using oxygen, and the failure to accept the findings of pioneers in its application, handicapped for thirty years the introduction of a method which promises to revolutionize high-altitude mountaineering ... Until the Swiss expedition last year the only serious attempts to use it were those of Finch in 1922 and Lloyd in $1938 .{ }^{86}$

The 'futile controversy' - which we have seen is more substantial than Ward and Pugh would have us believe-did not stop oxygen being taken on every full British expedition. Mallory and Irvine climbed to their deaths apparently convinced of the utility of oxygen, carrying systems which they had personally and meticulously trialled and reconfigured (in Mallory's case over several expeditions). ${ }^{87}$ Oxygen systems were carried, tested and technically altered in the 1930s despite the ambiguous results their experimental use had demonstrated in the 1920s. Further, on every expedition, even those with no official scientific programme, physiological work was carried out; in 1922 and 1933 attempts were made to take alveolar samples above seven thousand metres, a task which proved extremely difficult and which was not successfully done on the summit until $1981 .{ }^{88}$

\section{8: The gasping lung}

The first explicitly physiological expedition to the Everest region took place as part of what became known as the Silver Hut Expedition of 1960-1961 (so named because of the silver paint used on the expedition's prefabricated hut). ${ }^{89}$ Pugh and Hillary developed a scheme to use polar-style tactics - overwintering, after both experiencing an Antarctic expedition, Pugh in 1957-1958 with the Anglo-American Antarctic Physiological Expedition, and Hillary in 1958 with the Commonwealth Trans-Antarctic Expedition. ${ }^{90}$ Links between polar exploration and high-altitude expeditions are

85 G.T. Stewart, 'The British reaction to the conquest of Everest', Journal of Sport History (1980) 7, pp. 21-39.

86 Pugh and Ward, op. cit. (59), p. 276. Pugh was less critical when addressing the RGS: L.G.C.E. Pugh, 'Scientific aspects of the expedition to Mount Everest, 1953', Geographical Journal (1954) 12, pp. 183-192.

87 Mallory, op. cit. (83), pp. 410-411.

88 Greene, op. cit. (3); T.H. Somervell, 'Note on the composition of alveolar air at extreme heights', Journal of Physiology (1925) 60, pp. 282-285.

89 Formally, 'The 1960-61 Himalayan Scientific and Mountaineering Expedition'. James S. Milledge, 'The Silver Hut Expedition, 1960-61', High Altitude Medicine \& Biology (2010) 11, pp. 93-101; L.G.C.E. Pugh, 'Himalayan scientific and mountaineering expedition 1960-61: the scientific programme', Geographical Journal (1962) 128, pp. 447-456.

90 Pugh's work on a largely American team was sponsored (to the tune of $£ 2,300$ ) by the Wellcome Trust; Hillary's was paid for by the government of New Zealand. Anon., 'Medical news', British Medical Journal (1957) 2, pp. 1061-1062. 
strong throughout the twentieth century, with polar equipment and rations providing important 'starting points' for the development of high-altitude equipment. ${ }^{91}$

The research done in the Silver Hut at 5,800 metres and on the slopes of neighbouring 'eight-thousanders' is a touchstone for most research in this area for the rest of the century. While respiration, fatigue and blood composition were all studied at Silver Hut, the issue of human survival at 8,848 metres without oxygen does not seem to have been as important as in previous years. The debate about oxygen went into effective abeyance after 1953; researchers had other questions to ask the mountain. This extremely detailed work into the biochemical, physiological and genetic processes of adaptation, done at multiplying high-altitude research stations, increasingly drew conclusions that were more about sea-level illnesses, normal respiratory and circulatory functions, emergency medical care on expeditions, human evolution and sports science than they were about mountaineering above 8,700 metres.

Physiologists and mountaineers still discussed the issue; Pugh had been amongst the first to criticize Houston's mapping between standard atmospheres and 'real-world' altitudes, but his Silver Hut figures, when extrapolated, also seemed to show that an oxygenless ascent of Everest was at the extreme limit of human ability. ${ }^{92}$ Ward had a more optimistic approach, writing retrospectively, 'We concluded theoretically ... that on the summit of Everest, the barometric pressure would be high enough and the intake of naturally available oxygen great enough for climbers to be able to move slowly without the help of supplementary oxygen' (though whether this pace would allow a survivable summit attempt was not clear). ${ }^{93}$ Others continued to maintain that it was an impossible task. ${ }^{94}$ Hillary and Tenzing had taken a few tentative breaths on the summit, but beyond this it appeared at the limits of possibility for a human being to expend the energy necessary to climb to the summit without any supplemental gas. ${ }^{95}$

Then, in May 1978, Peter Habeler and Reinhold Messner did exactly that. Later Messner described his experience of being on the summit in a now famous quotation: 'I am nothing more than a single narrow gasping lung, floating over the mists and summits'. ${ }^{96}$ The conclusions that physiologists drew from this - once they had got over any initial scepticism - was that obviously it must be the model that was wrong; the mountain could not err. ${ }^{97}$ Since the first critiques of Paul Bert's work, climbing

91 E.g. Mosso, op. cit. (24), pp. 314-316.

92 L.G.C.E. Pugh et al., 'Muscular exercise at great altitudes', Journal of Applied Physiology (1964) 19, $431-440$.

93 John West, 'Climbing Mt. Everest without oxygen: an analysis of maximal exercise during extreme hypoxia', Respiration Physiology (1983) 52, pp. 265-279.

94 E.g. N.E. Odell, 'So-called "deterioration” and the use of oxygen at high altitudes', Geographical Journal (1954) 120, pp. 131-133.

95 Hillary himself maintained a belief that Everest was scalable without oxygen, writing in 1976, 'I have always thought that men could reach the top of Everest without any use of oxygen'. Hillary to West, 23 February 1976, Mandeville/West, Box 74, Folder 15.

96 Quoted in R.B. Schoene, 'Limits of human lung function at high altitude', Journal of Experimental Biology (2001) 204, pp. 3121-3127, 3121.

97 The first direct measure of barometric pressure on Everest's summit was not taken until 1981, and, as the physiologist and historian Kellogg wrote, 'The physiologist ... is somewhat relieved to find that the barometric pressure is indeed elevated above the standard US Atmosphere value...f for that reduces the problem of 
physiologists had been arguing for the privileging of 'facts' made on mountains over those made in barometric chambers; Messner and Habeler's ascent was the unarguable confirmation that many physiologists, and mountaineers, had been waiting for.

The first oxygenless ascent, asserting the primacy of the field, certainly reinvigorated research interest in the very high altitudes of the Himalaya. It is only possible here to give an outline of such work after 1978: we should start with the American Medical Research Expedition to Everest (AMREE), led by John West in 1981, which was the first expedition whose aims were explicitly biomedical, and yet set its sights on the summit. The team was divided into three categories: the climbers, the scientists and the climbing scientists; climbers were to aim for the summit and act as guinea pigs, the scientists were to remain in the two laboratories constructed on the mountain at 5,830 metres and 6,100 metres, and the climbing scientists acted in both roles. Two of the climbing scientists successfully reached the summit of Everest, one managing to take an alveolar air sample on the roof of the world - the first clinical measurement of a human being taken there. ${ }^{98}$

Shortly after AMREE, Charlie Houston led a grant bid to the National Institutes of Health for funding for 'Operation Everest II', a longer, more extensive version of his pioneering barometric chamber work in the 1940s; after initial difficulties the project received funding in $1985 .{ }^{99}$ The study drew criticism at the time the bid was made, and subsequently, from other high-altitude researchers (particularly those involved with AMREE), not least because Houston persisted with a standard atmosphere model of altitude, mixed 'confusingly' with field-based measurements of pressure on Everest. ${ }^{100}$ This admixture of models and measurements made early papers difficult to interpret, and later publications dropped the altitude conversions entirely, instead listing just barometric pressure in torr. ${ }^{101}$

The failure of subjects in barometric chambers to acclimatize as mountaineers do was a persistent problem for laboratory studies, and was used as a convincing argument for the need for field trips. In the research plans for Operation Everest II, it appears almost as a requirement that the barometric chamber be used only for studies that would have been impossible to conduct at high altitude. Laboratory studies-even in the research proposal for a laboratory study - are figured as second-best options for work which, requiring specialist equipment or potentially risky medical interventions, simply could not be done on a mountain for technical or ethical reasons. As a mirror to this, AMREE's justification was that Everest was a unique research site-a 'natural laboratory'-able to produce results which had real-world applications and yet could

explaining adequate oxygen supply for survival.' Kellogg to West, 10 January 1981, Mandeville/West, Box 10, Folder 14.

98 One climber and two Sherpa also reached the summit. John West, 'Man at extreme altitude', Journal of Applied Physiology (1982) 52, pp. 1393-1399.

99 These difficulties, as with debates earlier in the century, were technical, personal, ideological and ethical. See Mandeville/West, Box 89, Folder 4.

100 West, op. cit. (7), p. 350. West to Houston, 11 September 1987, Mandeville/West, Box 8, Folder 27. West to Schoene, 25 July 1987, Mandeville/West, Box 26, Folder 27.

101 West, op. cit. (7), p. 352. 
not possibly be modelled in any other site. ${ }^{102}$ The justifications for an Everest trip had to be extraordinarily robust - after all, the mortality rate for a summit expedition is a staggering one in twenty, considerably higher than would be acceptable in nearly any other sort of clinical study or trial. The AMREE was approved by the National Heart, Lung, and Blood Institute, the National Geographic Society and the American Thoracic Society, despite a genuine risk of death for the participants. ${ }^{103}$

By the 1980s, then, Everest and other very high-altitude research spaces were the gold standard for generating 'facts' about respiratory and cardio-pulmonary physiology that were relevant at both altitude and sea-level. The barometric chamber and other sea-level systems were back-ups, last resorts or sites where research was 'practised' before it was taken to final arbitration on the mountainside. The first large-scale mixed-sex clinical studies conducted on Everest-run by the Caudwell Xtreme Everest group-have research organized in what can usefully be thought of as a 'staging' system. Members and affiliates first design projects within a laboratory/sea-level setting; successful bids for research slots are allowed space at permanent mid-altitude research laboratories (in this case the renovated Capanna Margherita); finally, once their value and practicality are proved and the techniques refined, a further selection takes the projects to Everest - base station, temporary laboratory or summit study. ${ }^{104}$

High-altitude physiology has always prioritized the field over the laboratory; its major figures have always been those who, like Mosso, climbed themselves, not those who, like Bert, stayed in the laboratory (although some, such as Haldane, were reluctant mountaineers). Although most accounts of the history of this sort of respiratory physiology begin with Bert-this one being no exception-the fetishization of a laboratory-based explanation appears to be a historical artefact. Bert's conclusions were immediately criticized, and through the twentieth century physiologists and doctors such as Pugh and Ward have systematically and consistently queried the conclusions drawn by 'armchair theorists' in the face of conflicting experiences on the mountainside.

High-altitude physiology is a speciality where multiple types of investigation, multiple sites of research and multiple competencies are welcomed into projects; where facts generated from across disciplines, by scientists as well as by those with other skills, are synthesized. Perhaps most interesting, though, given the traditional stories about the rise of molecular biology and the Big Science of physics and biology, is this sort of physiology's definite emphasis on the field. Everest is a unique, unreplicable research site; excitingly, over the twentieth century it was reconstructed as a place which could itself - just like a laboratory - provide universal facts about the human body. And often these facts are about a holistic, whole-body physiology, where processes such as

102 The phrase 'natural laboratory on the mountain' is explicitly used by Pugh to highlight the issue of acclimatization. Memo from Pugh to [physicist] Sheldon Shultz, 9 February 1982, Mandeville/Pugh, Box 15, Folder 32.

103 Although the risk of death on a medical expedition with carefully screened participants and heavy medical support is probably significantly lower than that on less selective 'commercial' expeditions.

104 Some of these ideas were consolidated by attending meetings of the Caudwell Xtreme Everest group in London, in December 2009 and February 2010. I would like to thank the group for letting me sit in on their meetings, and particularly Dr Andrew Murray and Dr Mike Grocott. 
acclimatization are represented as impossible to understand through reductive practices in medicine or biology. ${ }^{105}$

This reconstruction of a mountain occurred over a century of climbing and researching. At every stage the political situation in the Himalaya and in researchers' home nations directed and shaped this work; at every stage the needs and goals of other groups - climbers, Sherpas, anthropologists, civil servants, geographers, newspapers were folded into research goals and the design of research projects. This was High Science if not Big Science, drawing funding from diffuse sources, often including military (and later space-science) interests as well as large-scale medical research organizations, and creating complicated connections between scientific disciplines and scientists who otherwise seemed to have nothing in common. Reconsidering the history of twentiethcentury physiology also poses some intriguing contradictions which will help us rewrite our larger narratives of experimental sites and practices; in 1967 the Medical Research Council, in an attempt to please Dr Pugh, who was unsatisfied with the conditions of employment he faced, offered him his own (small) institution. Its title is, on first reading, a contradiction in terms, but perfectly fits the work he had been involved in around Everest (and in Antarctica): he became the head of the Laboratory for Field Physiology. 106

105 There is much more that is of interest to historians of science and medicine in the work done on, near, for and about Everest. Climbing and research expeditions are models of international cooperation and often pose awkward problems of technological and methodological incommensurability. Funding is also worth exploring, as most expeditions are paid for by multiple interests with sometimes competing desires - the Silver Hut Expedition had money from the Daily Mail to undertake a hunt for the Yeti. Expeditions also involve close working with local people, guides and Sherpa. On Yeti spotting, see Edward Wyss-Dunant, 'The first Swiss expedition to Mount Everest, 1952', Geographical Journal (1953) 119, pp. 266-277; for lyrical work on the Sherpa see Sherry Ortner, Life and Death on Mt. Everest: Sherpas and Himalayan Mountaineering, Princeton: Princeton University Press, 1999.

106 Medawar to Pugh, 29 November 1967, Mandeville/Pugh, Box 8, Folder 39. 